\title{
Primary Malignant Melanoma of the Small Bowel with Hepatic Metastasis: A Case Report
}

\author{
Jei Hee Lee, Jimi Huh \\ Department of Radiology, Ajou University School of Medicine, Suwon, Korea
}

Primary intestinal melanoma is extremely rare, whereas metastatic melanoma of the small bowel is common. In this report, we present a rare case of primary small bowel melanoma with hepatic metastasis. A 51-yearold man presented with constipation and CT identified an ileal mass without bowel obstruction. CT and MRI revealed hepatic metastasis. Ileal mass was confirmed on laparotomy and histologically diagnosed as melanoma.

Keywords: Malignant melanoma; Small bowel; Computed tomography; Magnetic resonance

\section{Introduction}

Malignant melanomas typically occur in the skin but may rarely occur in the mouth, intestines or eye (uveal melanoma). Malignant melanoma in gastrointestinal (GI) tract is an uncommon entity, most often seen as metastatic disease from cutaneous lesions (1). Primary small bowel melanoma (PSBM) is very rare and only limited cases of PSBM have been reported worldwide. We here report a rare case of primary malignant melanoma of the small bowel with hepatic metastasis.

\section{Case Report}

A 51-year-old man visited the authors' institution complaining of constipation for one month and mild fever for a week. No other symptoms, such as abdominal pain or weight loss, were noted. His past medical history was unremarkable, except he had performed cholecystectomy five years ago. On the physical examination, the abdomen was soft and non-tender, and no mass was palpable. Laboratory investigations revealed mild anemia and elevated C-reactive protein level (hemoglobin, $10.1 \mathrm{~g} /$ $\mathrm{dL} ;$ C-reactive protein, $24.4 \mathrm{mg} / \mathrm{L}$ ). Therefore, abdominal computeted tomography (CT) was performed for evaluation of fever focus and to exclude small bowel bleeding.

CT scan revealed about $9.5 \mathrm{~cm}$ size lobulated mass in the ileum with heterogenous contrast enhancement (Fig. 1A). Multiple enlarged lymph nodes around the tumor were noted. There was no evidence of obstruction. Initial assessment based on CT findings was lymphoma. The differential diagnosis included gastrointestinal stromal tumor (GIST) or primary ileal adenocarcinoma. Multiple small nodules are seen in the liver, which were regarded as hepatic lymphoma or metastasis (Fig. 1B).

\footnotetext{
Received: June 14, 2021 Revised: June 22, 2021 Accepted: June 22, 2021

Correspondence: Jei Hee Lee, MD

Department of Radiology, Ajou University School of Medicine, 164, World cup-ro, Yeongtong-gu, Suwon-si, Gyeonggi-do 16499, Korea

Tel: +82-31-219-5852 Fax:+82-31-219-5862 E-mail: radljh@ajou.ac.kr

This is an Open Access article distributed under the terms of the Creative Commons Attribution Non-Commercial License (http:// creativecommons.org/licenses/by-nc/4.0/) which permits unrestricted non-commercial use, distribution, and reproduction in any medium, provided the original work is properly cited.
} 


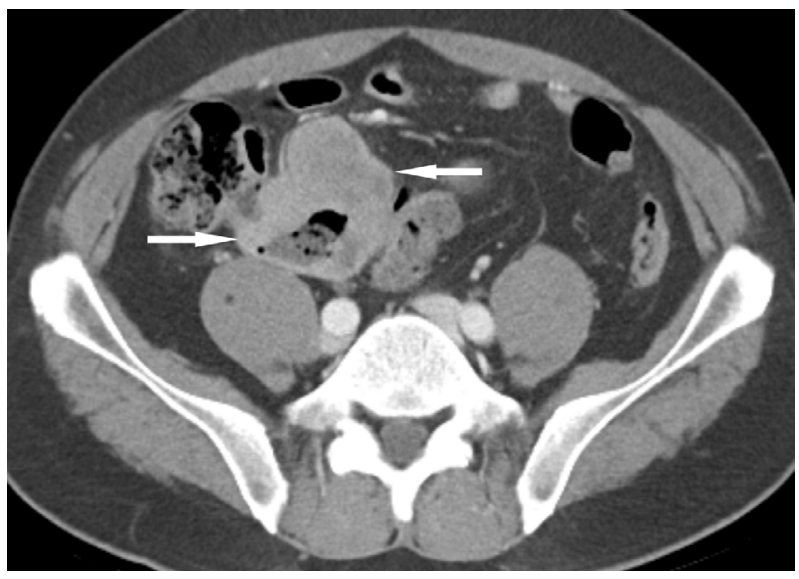

A

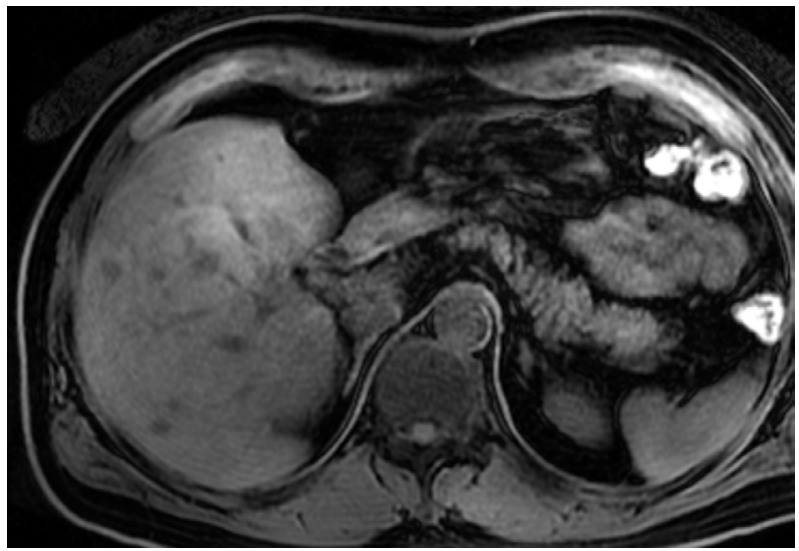

C

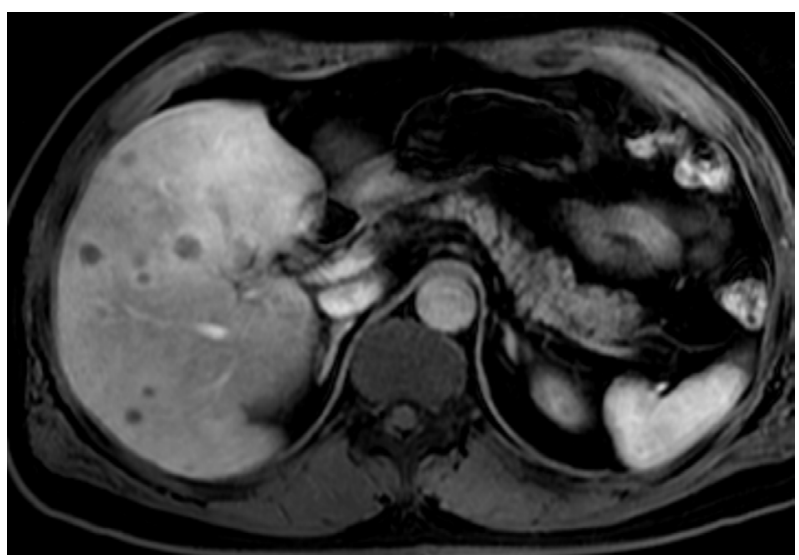

E

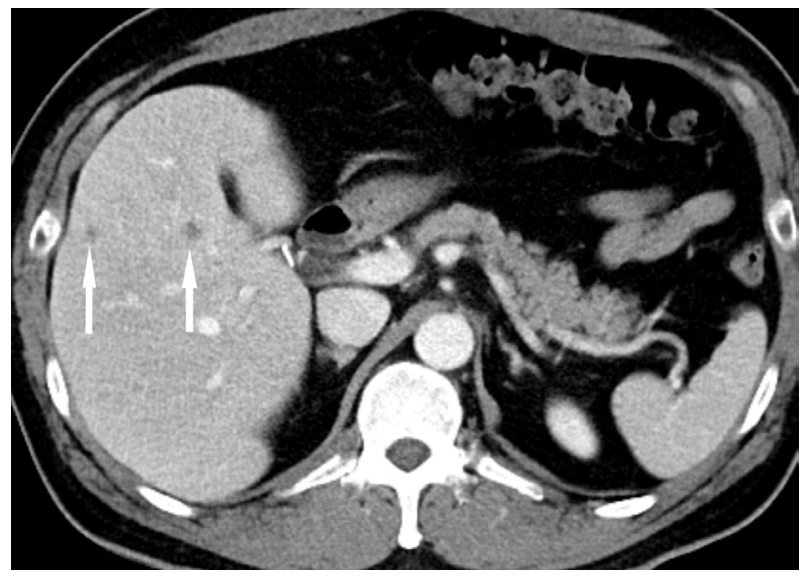

B

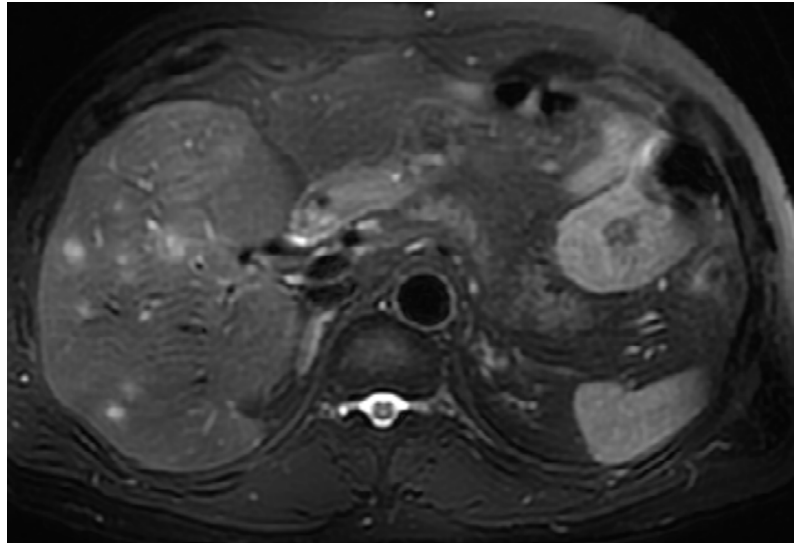

D

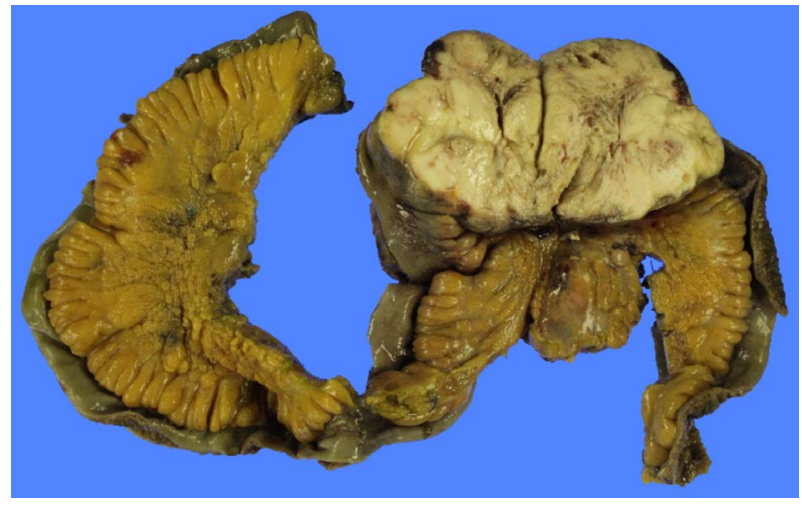

$\mathrm{F}$

Fig. 1. Primary malignant melanoma of the small bowel in a 51-year-old male patient.

A. CT scan shows about $9.5 \mathrm{~cm}$ size lobulated mass (arrows) in the ileum with heterogenous contrast enhancement. B. CT scan shows multiple ill-defined small low density nodules (arrows) in liver. C. T1-weighted liver MR image shows multiple hypointensity hepatic nodules in liver. D. T2-weighted liver MR image shows multiple hyperintensity hepatic nodules in liver. E. T1-weighted image on late arterial phase shows multiple peripheral enhancing target-like nodules in liver. F. Grossly specimen of the mass shows ileum origin whitish mass. 
Magnetic resonance (MR) imaging of liver was performed, which revealed more hepatic nodules than CT. And there was size discrepancy between CT and MR. Multiple liver lesions show low signal intensity (SI) on T1 (Fig. 1C), and high SI on T2 (Fig. 1D), and target appearance contrast enhancement of late arterial phase (Fig. 1E). Low signal intensity on hepatobiliary phase and diffusion restriction was noted in the multiple liver lesions. The final assessment was malignant GIST with hepatic metastasis.

The patient underwent segmental resection of the ileum. The mass was located $50 \mathrm{~cm}$ above the ileocecal valve. On gross examination, exophytic soft mass was identified in the ileal wall and multiple enlarged lymph nodes are noted in mesentery.

Grossly the mass exhibited whitish mass (Fig. 1F) and microscopic examination revealed infiltration of epithelioid cells with prominent nucleoli. On immunohistochemistry, the tumor cells were negative for c-kit, CD34, D0G-1, Actin, and Melan-A, but the tumor cells were positive for HMB45 and S-100 protein. The final diagnosis was malignant melanoma of the small bowel.

\section{Discussion}

Malignant melanomas constitute $1 \%-3 \%$ of all malignant tumors of the $\mathrm{GI}$ tract (2). Primary mucosal melanoma can arise at any site within the Gl mucosa, but it is most common in anorectal (53.6\%) and oropharyngeal (32.8\%) regions, whereas esophagus $(5.9 \%)$, stomach $(2.7 \%)$, small bowel $(2.3 \%)$, gallbladder $(1.4 \%)$, and colon $(0.9 \%)$ are extremely rare sites of origin (1).

The origin of PSBM remains unknown, because small bowel contains no melanocystes. One potential origin of the primary melanoma of small bowel is melanoblastic cells of the neural crest that migrate to the distal ileum through the omphalomesenteric canal. A second theory suggest that these tumors originate from enteric neuroendocrine noncutaneous tissue in the form of amine precursor uptake decarboxylase cells, which undergo neoplastic transformation (3). Most of malignant melanomas in the small bowel are metastases from primary cutaneous lesions, but a clear distinction between primary intestinal melanoma and intestinal metastasis can be difficult when considering histopathological features alone (3). A primary GI mucosal melanoma is considered in patients with no obvious primary cutaneous melanoma or those with an isolated Gl lesion in the absence of other extraintestinal metastases. Blecker et al. (4) suggest the criteria for a diagnosis of primary intestinal melanoma: no evidence of concurrent melanoma or atypical melanocytic lesion of the skin, absence of extraintestinal metastatic spread of melanoma, and presence of intramucosal lesions in the overlying or adjacent intestinal epithelium. Another criteria of Sachs et al. (5), primary small bowel melanoma is a solitary lesion, has no metastatic lesions other than those of regional lymph nodes at diagnosis, and has a disease-free survival period of at least 12 months after diagnosis.

Bender et al. (6) defined four different types of metastatic melanoma of the small bowel: polypoid, cavitary, infiltrating, and exoenteric. Among 32 patients, the polypoid pattern was seen in 20 patients $(63 \%)$, and the "target lesion," a discrete polypoid mass with a central ulceration, was observed in only three $(9 \%)$ of the 32 patients. Six of whom showed multiple polypoid lesions (more than 10) referred to as polyposis. Eight patients (25\%) demonstrated a cavitary pattern, a circumferential mass with inner marginal necrosis, and five (16\%) showed an infiltrating pattern. One patient (3\%) had an exoenteric lesion with a fistulous tract. Because primary small bowel melanoma is very rare, there has been no report for imaging features and gross morphologic types (7). Our case can be categorized as exoenteric type according to Bender's categorization, that mimic small bowel lymphoma of GIST.

Hepatic metastasis is a common feature in the advanced stage of malignant melanoma. Detection of hepatic metastases provides valuable prognostic information and critical impact for the therapeutic plan (8). Although CT can provide a limited specificity for the detection of hepatic metastasis in patients with malignant melanoma, but MR imaging was more useful in the detection of hepatic metastasis (8). Typical MR imaging features of hepatic metastasis of malignant melanoma shows shortened T1 and $\mathrm{T} 2$ relaxation times and the presence of $\mathrm{T} 1$ shortening closely related to the melanin content of the lesion. Although it is rare, we should consider that T1-shortning effects may be caused by extracellular methemoglobin, 
fat, and high protein content (9). In our study, MR shows higher sensitivity for detection of hepatic metastasis of malignant melanoma than CT. But low to iso-intensity on fat-suppressed T1-weighted images and high intensity on fat-suppressed T2-weighted images were identified in our case of amelantoic melanoma.

In summary, we reported a rare case of primary SBM with hepatic metastasis mimic small bowel lymphoma or GIST. Primary SBM is a rare tumor without a history of melanoma in another organ. For the early detection of primary SBM, clinical examination including imaging studies and pathologic examination is essential.

ORCID: Jei Hee Lee: https://orcid.org/0000-0002-2231-820X; Jimi Huh: https:// orcid.org/0000-0002-8832-6165

\section{References}

1. Cheung MC, Perez EA, Molina MA, Jin X, Gutierrez JC, Franceschi $D$, et al. Defining the role of surgery for primary gastrointestinal tract melanoma. J Gastrointest Surg 2008; 12:731-738.

2. Atmatzidis KS, Pavlidis TE, Papaziogas BT, Papaziogas TB. Primary malignant melanoma of the small intestine: report of a case. Surg Today 2002;32:831-833.
3. Lens $M$, Bataille $V$, Krivokapic Z. Melanoma of the small intestine. Lancet Oncol 2009;10:516-521.

4. Blecker D, Abraham S, Furth EE, Kochman ML. Melanoma in the gastrointestinal tract. Am J Gastroenterol 1999;94:34273433.

5. Sachs DL, Lowe L, Chang AE, Carson E, Johnson TM. Do primary small intestinal melanomas exist? Report of a case. J Am Acad Dermatol 1999;41:1042-1044.

6. Bender GN, Maglinte DD, McLarney JH, Rex D, Kelvin FM. Malignant melanoma: patterns of metastasis to the small bowel, reliability of imaging studies, and clinical relevance. Am J Gastroenterol 2001;96:2392-2400.

7. Yang KM, Kim CW, Kim S-W, Lee JL, Yoon YS, Park IJ, et al. Primary malignant melanoma of the small intestine: a report of 2 cases and a review of the literature. Ann Surg Treat Res 2018;94:274-278.

8. Sofue K, Tateishi U, Tsurusaki M, Arai Y, Yamazaki N, Sugimura K. MR imaging of hepatic metastasis in patients with malignant melanoma: evaluation of suspected lesions screened at contrast-enhanced CT. Eur J Radiol 2012;81:714-718.

9. Kelekis NL, Semelka RC, Woosley JT. Malignant lesions of the liver with high signal intensity on T1-weighted MR images. J Magn Reson Imaging 1996;6:291-294.

\title{
간전이를 동반한 원발성 소장 흑색종: 증례보고
}

\author{
이제희, 허지미 \\ 아주대학교병원 영상의학과
}

\section{초 록}

원발성 장관 흑색종은 매우 드물며, 전이성 소장 흑색종이 가장 흔하다. 이 증례보고는 원발성 소장 흑색종이 간전이 를 한 드문 증례이다. 51세 남환이 변이 주소로 내원하였고, CT에서 장 폐쇄가 없는 회장의 종괴가 발견되었다. CT와 $\mathrm{MRI}$ 에서 간전이가 발견되었다. 회장의 종괴는 개복술을 통하여 확인되었고, 조직학적으로 흑색종으로 진단되었다. 